\title{
DAMPAK PROMOSI DIGITAL LINE TERHADAP KEPUTUSAN PEMBELIAN PELANGGAN DUNKIN DONUTS
}

\section{The Impact of Digital Line Promotion on Dunkin Donuts's Customer Buying Decision}

\author{
Dina Mayasari Soeswoyo ${ }^{1)}$, David Tumbelaka ${ }^{2)}$ \\ ${ }^{1)}$ Diploma Empat Perhotelan, Sekolah Tinggi Pariwisata Bogor \\ ${ }^{2)}$ Diploma Empat Perhotelan, Sekolah Tinggi Pariwisata Bogor
}

29 April 2020

\begin{abstract}
Advances in technology and communication have triggered an increase in the use of social media in Indonesia. Social media as a means of communication is then chosen by marketers as one of the opportunities to carry out promotions as done by Dunkin Donuts utilizing the LINE social network. The large number of followers and various forms of promotion carried out, it is very interesting to study to determine the impact on purchasing decisions of its customers.

This research uses a quantitative approach with 100 respondents used as the study sample are active LINE users who follow the official Dunkin Donuts account and are customers of Dunkin Donuts Sukasari, Bogor. Data collection is done by using a questionnaire that has been tested for validity and reliability. The classic assumption test is performed as a prerequisite for regression. Data were analyzed using simple linear regression analysis, T-Test, Correlation Coefficient Test and Determinant Coefficient.

Based on the results of the study concluded that the promotion of digital LINE had a significant positive impact on customer buying decisions at Dunkin Donuts Sukasari-Bogor with a contribution of $58.2 \%$, while the remaining $41.8 \%$ was influenced by other variables not examined
\end{abstract}

Keywords: Digital Promotion, LINE Social Network, Buying Decisions, Dunkin Donuts

Kemajuan teknologi dan komunikasi memicu peningkatan dalam penggunaan media sosial di Indonesia. Media sosial sebagai sarana komunikasi kemudian dipilih oleh pemasar sebagai salah satu peluang untuk melakukan promosi sebagaimana dilakukan oleh Dunkin Donuts yang memanfaatkan Jejaring sosial LINE. Banyaknya jumlah pengikut dan aneka ragam bentuk promosi yang dilakukan, sangat menarik untuk dikaji untuk mengetahui dampaknya terhadap keputusan pembelian para pelanggannya.

Penelitian ini menggunakan pendekatan kuantitatif dengan sampel penelitian sebanyak 100 responden yang merupakan pengguna aktif LINE pelanggan Dunkin Donuts Sukasari Bogor yang mengikuti akun resmi Dunkin Donuts. Pengumpulan data dilakukan dengan menggunakan kuesioner yang telah diuji validitas dan reliabilitasnya. Uji asumsi klasik dilakukan sebagai prasyarat regresi. Data dianalisis menggunakan analisis regresi linier sederhana, Uji-T, Uji koefisien Korelasi serta Koefisien Determinan.

Berdasarkan hasil penelitian diperoleh kesimpulan bahwa promosi digital LINE memberi dampak yang positif signifikan terhadap keputusan pembelian pelanggannya di Dunkin Donuts Sukasari-Bogor dengan kontribusi pengaruhnya sebesar $58,2 \%$, sedangkan sisanya sebesar $41,8 \%$ dipengaruhi oleh variabel lain yang tidak diteliti

Kata Kunci : Promosi digital, Media Sosial LINE, Keputusan Pembelian, Dunkin Donuts

\section{PENDAHULUAN}

Era globalisasi berdampak terhadap percepatan perkembangan teknologi secara signifikan sehingga masyarakat dipermudah dalam memenuhi kebutuhannya termasuk di antaranya dalam bidang komunikasi. Salah satu hasil perkembangan teknologi adalah internet di mana hampir seluruh masyarakat Indonesia maupun internasional membutuhkan internet untuk membantu mencari berbagai informasi, menyampaikan pesan atau berita, untuk hiburan, atau memenuhi kebutuhan lainya.

Menurut Sibero (2011), Internet atau yang merupakan kependekan dari Interconnected Network merupakan sebuah jaringan komputer yang menghubungkan antar 
komputer secara global. Internet juga dapat bekerja sama seperti jaringan komputer pada umumnya, mencapai jutaan komputer di seluruh dunia yang dapat saling berhubungan serta saling terkoneksi satu sama lainnya. Agar komputer dapat saling terkoneksi satu sama lain, maka diperlukan media untuk saling menghubungkan antar komputer. Media yang digunakan itu bisa menggunakan kabel/serat optik, satelit atau melalui sambungan telepon (Harjono, 2009). Internet juga menggunakan sebuah protokol komunikasi yang sama yaitu TCP/IP (Tranmission Control Protol / Internet Protocol).

. Menurut survei Asosiasi Penyelenggara Jasa Internet Indonesia (APJII), jumlah pengguna internet di Indonesia tahun 2017 adalah 143,57 juta pengguna setara dengan $54,4 \%$ dari total penduduk Indonesia. Berdasarkan wilayah, pengguna internet terbanyak ada di Pulau Jawa sebesar 58,1\% dari total pengguna internet atau, sekitar 83,4 juta pengguna. Berdasarkan layanan yang diakses, pengguna terbanyak adalah layanan chatting sebesar $89,4 \%$ atau sekitar 128 juta pengguna, pengguna social media sebesar $87,1 \%$, dan pengguna search engine sebesar 74,8\% (APJII,2019).

Dunia digital yang berkembang saat ini tidak hanya menjadi sarana komunikasi, melainkan menghubungkan satu individu dengan individu lainnya yang tidak dibatasi oleh jarak dan keterbatasan waktu. Meningkatnya interaksi individu satu dengan lainya melalui dunia digital menjadikannya tidak hanya sebagai sarana komunikasi melainkan sebagai sarana perdagangan online atau E-commerce. Menurut Kotler dan Keller (2012: 460), E-commerce menggunakan website untuk bertransaksi atau memfasilitasi penjualan produk dan jasa secara online. Ecommerce merubah perilaku pembelian dari tradisional berbelanja di pasar, atau toko-toko menjadi hanya mengunjungi website dan memilih produk atau jasa yang ingin dibeli.

Perdagangan online (E-commerce) maupun cara konvensional tidak jauh dari kegiatan pemasaran dan strategi promosi untuk mendapatkan pelanggan sebanyak-banyaknya, hal ini berdampak pada semakin banyak persaingan dagang antar pengusaha sehingga para pengusaha dituntut selalu berinovasi dan kreatif dalam kegiatan pemasaran produk maupun jasa yang mereka tawarkan kepada konsumen untuk membentuk brand awareness dan loyalitas pelanggan. Menciptakan brand awareness, loyalitas dan kepuasan pelanggan menjadi salah satu tugas dari pemasaran. Komunikasi pemasaran memberikan informasi terkait suatu produk atau jasa yang dijual perusahaan kepada konsumen. Komunikasi pemasaran tak hanya digunakan oleh perusahaan akan tetapi, konsumen juga dapat melakukan komunikasi pemasaran kepada calon konsumen lainnya. Komunikasi pemasaran adalah aktivitas pemasaran yang berusaha menyebarkan informasi, mempengaruhi atau membujuk, dan atau mengingatkan pasar sasaran atas perusahaan dan produknya agar bersedia menerima, membeli dan loyal pada produk yang ditawarkan perusahaan yang bersangkutan sebagaimana disampaikan oleh Tjiptono (2001) dalam Rismayanti (2017).

Di dalam strategi pemasaran terdapat komponen promosi yang dilakukan untuk menarik minat calon konsumen dalam pengambilan keputusan apakah konsumen harus membeli suatu produk atau tidak yang dilakukan secara langsung, melalui dunia digital, maupun media massa. Promosi adalah koordinasi dari seluruh upaya pemasaran dalam membangun berbagai saluran informasi dan persuasi untuk menjual barang dan jasa, atau untuk memperkenalkan suatu gagasan (Morisson, 2010:16).

Promosi dapat dilakukan secara offline maupun online, namun seiring dengan perkembangan dunia teknologi, promosi melalui media digital lebih diminati karena dapat menjangkau banyak khalayak. Selain itu, media digital lebih efektif dan efisien serta tidak membutuhkan biaya yang sangat besar. Media digital yang dapat digunakan sebagai media promosi di antaranya meliputi media sosial maupun aplikasi messenger. Promosi dilakukan untuk menarik calon pembeli untuk membeli produk atau jasa yang ditawarkan sebanyak mungkin. Sebelum membeli produk maupun jasa, calon konsumen tentunya mempertimbangkan beberapa hal sebelum mengambil keputusan. Keputusan ini disebut dengan keputusan pembelian. Menurut Kotler dan Armstrong (2014: 158), Keputusan pembelian konsumen merupakan tahapan perilaku konsumen dalam menentukan 
keputusan akhir dalam membeli suatu produk atau jasa untuk kemudian dikonsumsi.

Fenomena yang terjadi tersebut menjadikan berbagai pengusaha menjadikan media sosial sebagai salah satu peluang untuk melakukan komunikasi pemasaran dalam mendekati konsumen. Bagi merek yang baru memanfaatkan media sosial tentu mempunyai tujuan untuk meningkatkan brand recognition dan awareness, mendapatkan konsumen baru dan melakukan akuisisi konsumen, namun bagi merek yang telah lama melakukan komunikasi pemasaran dengan media sosial tentu akan melakukan usaha untuk mengelola dan mempertahankan konsumen yang telah diperolehnya. Kegiatan promosi melalui dunia digital ini turut dilakukan oleh Dunkin Donuts yang merupakan perusahaan Internasional yang menjual berbagai variasi donat, makanan, serta minuman dan memiliki 200 gerai di Indonesia.

Sebagai salah satu restoran cepat saji popular di dunia, Dunkin Donuts yang telah memiliki lebih dari 11.000 gerai di 36 negara harus memilih media promosi yang tepat. Dari banyaknya aplikasi pesan messenger, Dunkin Donuts membuat akun resmi (official account) pada aplikasi LINE untuk melakukan komunikasi dengan pelanggan termasuk melakukan kegiatan promosi. Promosi yang diinformasikan sangat beragam, seperti harga khusus, promo gratis donat, e-coupon, cashback dan lain sebagainya.

Jejaring sosial LINE merupakan salah satu aplikasi chating yang sedang populer di dunia, sejak berdiri pada bulan maret 2011. Pada tahun 2016, LINE sudah mempunyai 400 juta pengguna di seluruh dunia dan 60 juta pengguna aktif di Indonesia. LINE dikenal dengan keunikan menggunakan emoticon yang inovatif yang dikenal dengan Stiker, selain itu menawarkan fitur-fitur lain di dalamnya seperti line games, line camera, line shoping dan lain-lain (www.tekno.kompas.com).

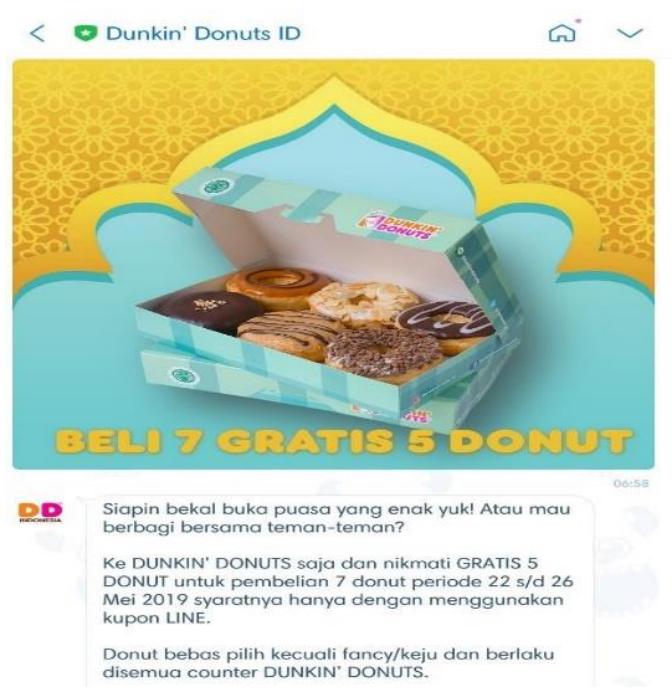

Gambar 1. Sales Promotion Dunkin Donuts Melalui LINE (( Dunkin Donuts, 2019)

Menurut Kotler dan Keller (2012), sales promotion atau promosi penjualan adalah variasi dari aktivitas jangka pendek untuk meningkatkan penjualan produk atau layanan, mencakup promosi konsumen (sampel, dan kupon), promosi dagang (iklan dan display) dan promosi bisnis.

Dunkin Donuts bekerjasama dengan media aplikasi LINE sebagai media promosi penjualan dengan memberikan broadcast berupa kupon, cashback, harga khusus, diskon dan promosi lainya untuk menarik pelanggan dan meningkatkan angka penjualan.

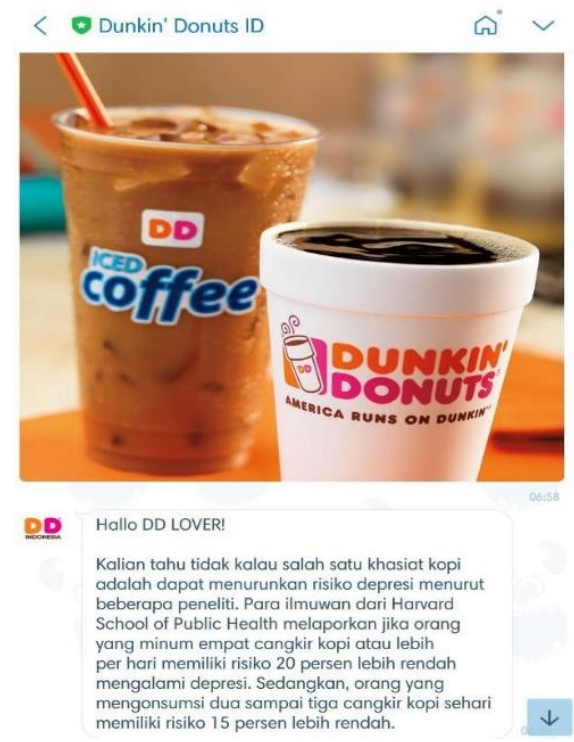

Gambar 2. Public Relation Dunkin Donuts Melalui LINE (Dunkin Donuts, 2019)

Dunkin Donuts menggunakan media aplikasi LINE sebagai media hubungan 
masyarakat dan publisitas secara eksternal dengan cara membagikan broadcast berupa informasi-informasi bermanfaat terkait produk yang ditawarkan, contohnya seperti manfaat kopi bagi kesehatan. Promosi yang diberikan Dunkin Donuts tentunya memberikan dampak terhadap kelangsungan perusahaan untuk mencapai suatu tujuan tertentu, termasuk keuntungan dan kerugian dalam implementasi berbagai bentuk promosi yang diberikan melalui aplikasi digital LINE, diantaranya: Mendapatkan konsumen baru, menarik konsumen dari pesaing, meningkatkan pembelian ulang, mempertahankan konsumen (loyalitas), meningkatkan angka penjualan, meningkatkan citra merek, memperbaharui stok, menguji seberapa tinggi harga resmi, serta evaluasi program dengan menganalisis perilaku konsumen (paska pembelian, saat pembelian, dan setelah pembelian). Dunkin Donuts memiliki sosial media lain termasuk Instagram yang diikuti sebanyak 447.000 pengikut, dan Facebook dengan jumlah pengikut 15.616.166. Sehingga dapat dikatakan Dunkin Donuts sudah banyak dikenal oleh masyarakat di Indonesia

Berdasarkan wawancara peneliti dengan Bapak Arif Kurniawan selaku store manager Dunkin Donuts Sukasari-Bogor, sebelum adanya promosi digital LINE angka penjualan lebih rendah dan target penjualan tidak selalu tercapai. Data 6 bulan terakhir menunjukan bahwa jumlah rata-rata transaksi adalah 120 orang per harinya termasuk pembeli yang menggunakan promosi LINE dengan data penjualan gerai sebagai berikut:

Tabel 1. Penjualan Donat di Dunkin Donuts Sukasari Bogor

\begin{tabular}{ccc}
\hline Bulan & Penjualan & Promosi LINE \\
\hline September 2018 & 10.834 Buah & 25.278 Buah \\
\hline Oktober 2018 & 11.705 Buah & 27.311 Buah \\
\hline November 2018 & 11.052 Buah & 25.788 Buah \\
\hline Desember 2018 & 11.620 Buah & 27.112 Buah \\
\hline Januari 2019 & 11.365 Buah & 26.518 Buah \\
\hline Februari 2019 & 11.076 Buah & 25.844 Buah \\
\hline Jumlah & & \\
\hline
\end{tabular}

Jumlah pengikut yang besar dan berbagai bentuk promosi yang diberikan pada akun resmi Dunkin Donuts melalui aplikasi LINE serta meningkatnya angka penjualan di gerai Dunkin Donuts Sukasari, Bogor, menarik untuk untuk dikaji dengan tujuan mengetahui dampak promosi digital LINE terhadap keputusan pembelian pengunjung. Penelitian ini dibatasi hanya pada satu Coffee house yaitu Dunkin Donuts yang beralamat di Jl. Siliwangi No.29, Sukasari, Bogor Timur, Kota Bogor, Jawa Barat. Dimensi promosi dibatasi hanya pada tiga (3) dimensi yaitu periklanan (advertising), promosi penjualan (sales promotion) serta hubungan masyarakat dan publisitas (public relation and publicity).

Penelitian ini diharapkan mampu memberikan pengetahuan dan pemahaman mengenai pengaruh promosi dengan menggunakan aplikasi LINE terhadap keputusan pembelian oleh pengunjung, dan diharapkan dapat memberikan informasi kepada Dunkin Donuts di Sukasari Bogor agar mengetahui begaimana pengaruh promosi melalui media aplikasi LINE terhadap keputusan pembelian pengunjung.

\section{Perilaku Konsumen}

Michael R. Solomon (2015:28) menjelaskan bahwa, perilaku pelanggan itu adalah studi yang mempelajari tentang proses ketika individu atau kelompok terlibat dalam melakukan pemilihan, pembelian, penggunaan, atau tidak menggunakan kembali berbagai produk, jasa, ide, atau pengalaman untuk memuaskan kebutuhan dan keinginan.

\section{Keputusan Pembelian}

Menurut Sumarwan (2014: 377), keputusan pembelian merupakan keputusan konsumen yang akan terjadi jika keinginan konsumen untuk membeli suatu barang sudah bulat yang meliputi mengenai barang apa yang akan dibeli, apakah membeli atau tidak, kapan membeli, dimana membeli, bagaimana cara membayarnya, dan sebagainya. Sedangkan menurut Peter-Olson dalam Setia (2012), keputusan pembelian merupakan "proses interaksi antara sikap afektif, sikap kognitif, dan sikap behavioral dengan faktor lingkungan di mana manusia melakukan pertukaran dalam semua aspek kehidupannya". Keputusan membeli atau tidak 
membeli merupakan bagian dari unsur yang melekat pada setiap individu yang disebut behavior, dimana merujuk pada tindakan fisik yang nyata yang dapat dilihat dan dapat diukur oleh orang lain.

Pembelian merupakan kegiatan dari suatu rangkaian fisik dan mental yang dilakukan oleh konsumen dalam melakukan pembelian. Dalam kegiatan pembelian terdapat suatu proses yang berujung pada pemilihan keputusan untuk membeli atau tidak membeli suatu produk dan penilaian terhadap perasaan puas atau tidak puas terhadap barang atau jasa yang ditawarkan.

Menurut Kotler dan Keler (2016: 195), umumnya pelanggan melalui lima tahap proses keputuan pembelian konsumen, yaitu Pengenalan Kebutuhan (Need Recognition), Pencarian Informasi (Information Search), Evaluasi Alternatif (Evaluation of Alternative), Keputusan Pembelian (Purchase decision), dan tahap Perilaku Pasca Pembelian (Postpuchase behaviour).

Dimensi dan indikator keputusan pembelian menurut Kotler dan Keller yang dialih bahasakan oleh Tjiptono (2012: 184) menjelaskan bahwa keputusan konsumen untuk melakukan pembelian suatu produk meliputi enam sub keputusan sebagai berikut: Pilihan Produk, Pilihan Merek, Pilihan Penyalur, Waktu Pembelian, Jumlah Pembelian, dan Metode pembayaran.

Menurut Kotler, Bowen \& Makens (2012), keputusan pembelian konsumen dipengaruhi oleh berbagai faktor internal dan eksternal. Faktor internal keputusan pembelian adalah pengaruh yang berasal dari dalam diri calon pembeli dalam pengambilan keputusan embelian, yaitu faktor-faktor seperti budaya, sosial, pribadi, dan pisikologis. Sedangkan faktor eksternal keputusan pembelian adalah pengaruh yang berasal dari luar diri calon pembeli dalam pengambilan keputusan pembelian seperti dari usaha pemasaran yang dilakukan oleh perusahaan dan informasi dari lingkungan konsumen. Faktor eksternal di antaranya meliputi produk, harga, lokasi dan promosi.

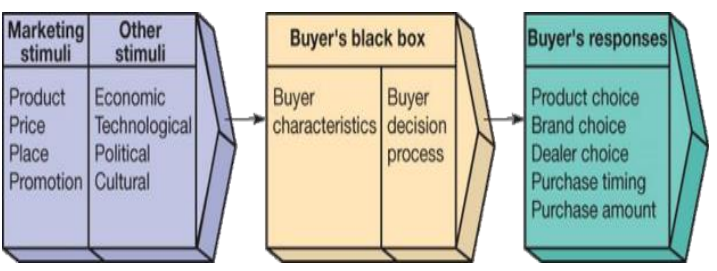

Gambar 3. Faktor Eksternal Keputusan Pembelian

Sumber: Kotler, Bowen dan Makens (2012)

\section{Promosi dan Bauran Promosi}

Promosi menurut Kotler dan Armstrong (2014: 77), merupakan berbagai aktifitas yang mengkomunikasikan produk atau jasa dalam membujuk konsumen untuk membelinya. Sedangkan menurut Tjiptono (2015: 387), Promosi merupakan salah satu komponen bauran pemasaran yang berupaya menginformasikan, membujuk, dan mengingatkan kembali kepada konsumen akan merek dan produk perusahaan.

Menurut Kotler dan Keller (2012), Integrated Marketing Communication atau bauran promosi (promotion mix) adalah sarana untuk menginformasikan, membujuk dan mengingatkan konsumen secara langsung. Agar perusahaan mencapai tujuan dari komunikasi, perusahaan dapat menggunakan alat bantu yang dinamakan marketing communication mix yang terdiri dari 8 unsur, yaitu: (1) Advertising, (2) Sales Promotion, (3) Event and Experiences, (4) Public relation and publicity, (5) Direct marketing, (6) Interactive marketing, (7) Word of Mouth Marketing, dan (8) Personal Selling

Dari kedelapan marketing communication mix atau bauran promosi tersebut, penelitian ini hanya menggunakan tiga variabel yaitu periklanan, promosi penjualan dan hubungan masyarakat sebagai dimensi penelitian. Dimensi tersebut digunakan mengingat Dunkin Donuts melakukan pendekatam promosi melalui media sosial LINE yang hanya mencakup tiga dimensi tersebut.

Menurut Kotler (2009), periklanan adalah bentuk promosi di berbagai media berbayar. Dari indikator terkait periklanan, peneliti menggunakan tiga indikator yaitu mission (tujuan), message ) pesan yang disampaikan), dan media (media promosi yang digunakan). Tidak 
dipilihnya indikator money dan measurement karena dari data periklanan perusahaan, indikator money dan measurement tidak dilakukan perusahaan Dunkin Donuts.

Pengertian promosi penjualan menurut Kotler dan Armstrong (2014:501) merupakan insentif jangka pendek untuk mendorong keinginan dan untuk mencoba atau membeli suatu produk/jasa. Adapun sifat-sifat terkait dalam melakukan promosi penjualan, antara lain: Komunikasi (communicate), Rangsangan (incentive), dan Undangan (invitation). Menurut Kotler dan Keller (2009) promosi penjualan memiliki indikator - indikator Frekuensi penjualan, Kualitas promosi, dan Ketepatan waktu. Dunkin Donuts melalui media digital LINE hanya menggunakan 3 (tiga) alat promosi, yaitu: a. Coupons yang berupa kupon elektronik yang di bagikan keseluruh pengguna LINE yang mengikuti akun resmi Dunkin Donuts dan berhak menukarkan kupon tersebut ke gerai Dunkin Donuts terdekat. b. Cash Refund Offer (Cashback) yang berupa berita promosi cashback 20\% yang dibagikan ke seluruh pengguna LINE yang mengikuti akun resmi Dunkin Donuts dengan menggunakan pembayaran melalui GO-pay. C. Price Packs (cents-off deals) yang berupa berita promosi harga khusus yang dibagikan kesuluruh pengguna LINE yang mengikuti akun resmi

Hubungan masyarakat menurut Kotler dan Keller (2012) adalah variasi program yang ditujukan secara internal untuk karyawan perusahaan dan secara eksternal untuk konsumen, perusahaan lain, pemerintah, dan media, untuk melindungi citra perusahaan. Kotler (2009) menguraikan beberapa indikator hubungan masyarakat (public relations) sebagai berikut : Berita yang berisikan informasi berita dari perusahaan yang ingin ditujukan kpada penerima dengan media tertentu, Kegiatan pelayanan masyarakat yang memiliki peran penting terhadap citra perusahaan, dan Identitas yang mencirikan citra perusahaan yang baik terhadap konsumennya.

\section{Promosi Digital (Digital Marketing)}

Menurut Sanjaya dan Tarigan (2009:47), Digital marketing adalah kegiatan marketing termasuk branding yang menggunakan berbagai media berbasis web seperti blog, website, e-mail, adwords, ataupun jejaring sosial. Menurut Heidrick dan Struggless (2009:1), perkembangan marketing melalui web, telepon genggam, dan perangkat games, menawarkan akses baru periklanan yang tidak digembor-gemborkan dan sangat berpengaruh.

Meyliana (2011) memaparkan bahwa emarketing merupakan bagian dari e-commerce yang merupakan sistem perdagangan melalui internet, di mana internet akan terus memberikan sifat yang up to date sehingga perusahaan dapat memberikan layanan informasi produk yang ditawarkan secara jelas dan mudah.

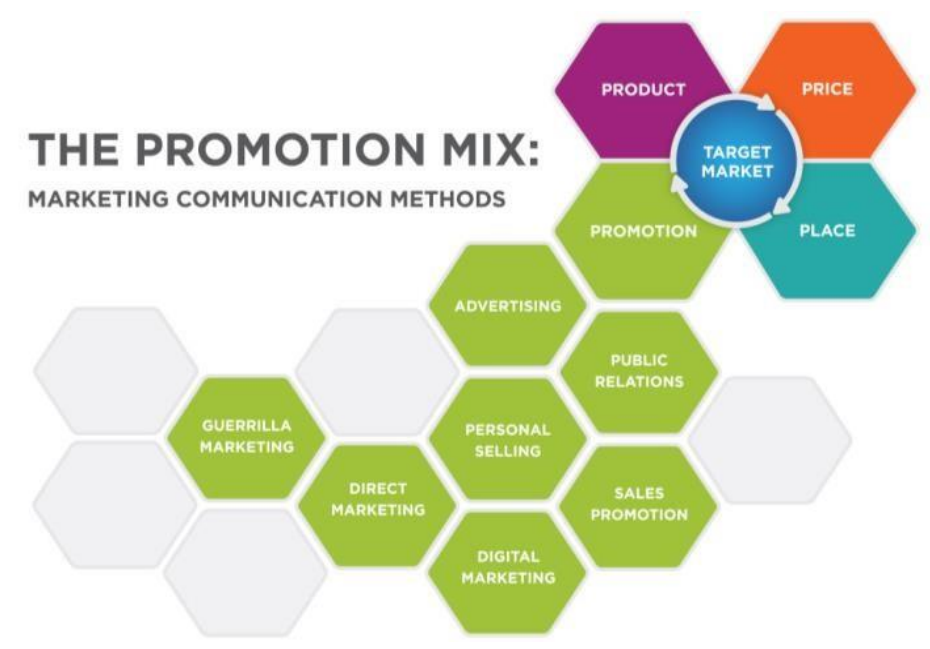

Gambar 4. Digital marketing salah satu komponen IMC (Meyliana, 2011) 
Pada ilustrasi Gambar 4. menunjukkan

bahwa digital marketing berada dalam lingkup IMC atau bauran promosi sebagai bagian yang bekerja untuk menginformasikan, membujuk dan mengingatkan konsumen secara online melalui media internet (website, blog, e-mail atau jejaring sosial) mengenai produk atau jasa yang ditawarkan oleh suatu organisasi atau perusahaan.

\section{Social Media}

Media sosial adalah sekelompok aplikasi berbasis internet yang dibangun atas dasar ideologis dan teknologi web 2.0, yang memungkinkan terjadi penciptaan dan pertukaran yang dihasilkan dari pengguna konten (Kaplan dan Haenlein, 2010). Sedangkan menurut Kotler dan Keller (2012), media sosial merupakan sarana bagi konsumen untuk berbagi teks, gambar, audio, dan video informasi satu sama lain dengan perusahaan dan sebaliknya. Menurutnya, jenis media sosial terbagi menjadi 3 yaitu (1) Online communities and forums yang dibentuk oleh sekelompok konsumen tanpa adanya pengaruh iklan dan afiliasi perusahaan di mana anggota yang tergabung dapat berkomunikasi dengan perusahaan dan satu anggota dengan anggota lainnya melalui posting, instant messaging, dan chat. (2) Blog yang merupakan catatan jurnal online yang diperbaharui secara berkala dan merupakan saluran yang penting bagi Word of Mouth. (3)Social networks dapat berupa situs jejaring sosial seperti Facebook, MySpace, Linkedln, dan Twitter. Neti (2011), menyatakan bahwa media sosial merupakan media untuk interaksi sosial dengan menggunakan teknik penerbitan sangat mudah diakses dan terukur.

\section{Social Media Marketing}

Social media marketing adalah sebuah proses yang mendorong individu untuk melakukan promosi melalui situs web, produk, atau layanan mereka melalui saluran sosial online dan untuk berkomunikasi dengan memanfaatkan komunitas yang jauh lebih besar yang memiliki kemungkinan lebih besar untuk melakukan pemasaran daripada melalui saluran periklanan tradisional (Weinberg, 2009: 3-4). Salah satu media sosial yang digunakan Dunkin Donuts dalam melakukan kegiatan periklanan atau promosi secara online adalah LINE yang merupakan applikasi messenger yang digunakan untuk berbagai kegiatan marketing.

Beberapa penelitian terdahulu tentang variabel keputusan pembelian yang dipengaruhi oleh berbagai variabel bebas, seperti yang dilakukan oleh Setia Tatang (2015) yang berjudul Pengaruh Periklanan, Promosi Penjualan, dan Hubungan Masyarakat terhadap Keputusan Wisatawan Berwisata Di Lembah Hijau Bandar Lampung; Dewi, Ni Made Arianita dan Elsie Oktivera (2018) yang berjudul Analisis Iklan Instant Messaging Line Mempengaruhi Minat Beli Konsumen Starbucks Di Jakarta Selatan ; Mileva, Lubiana dan Achmad Fauzi (2018) dalam penelitian tentang Pengaruh Social Media Marketing Line Terhadap Keputusan Pembelian di Starbuck, mereka menggunakan pendekatan yang berbeda-beda dengan hasil penelitian seluruhnya menyatakan adanya pengaruh variabel-variabel bebas tersebut terhadap keputusan pembelian.

Berdasarkan teori dan juga hasil dari beberapa penelitian sebelumnya, hipotesis penelitian ini adalah :

H1: Variabel promosi digital LINE berdampak positif terhadap keputusan pembelian di Dunkin Donuts Sukasari, Bogor.

\section{METODE PENELITIAN}

\section{Metode}

Penelitian ini dilakukan di Dunkin Donuts yang terletak di Jalan Siliwangi No.29, Sukasari, Bogor Timur, Kota Bogor, Jawa Barat. Metode penelitian yang dilakukan adalah kuantitatif yang merupakan penelitian positivis (positivitits) dengan menekankan pada pengujian-pengujian teori melalui pengukuran variabel-variabel penelitian dengan angka dan melakukan analisis data dengan statistika (Sugiarto et al, 2015). Peneliti menggunakan pendekatan survei, yaitu melakukan kegiatan pengumpulan data secara langsung ke lapangan dengan cara survei kepada responden yang dituju, tepatnya pendekatan survey crosssectional karena peneliti menetapkan jangka waktu tertentu dalam proses pengambilan datanya (Sugiarto et al, 2015). 


\section{Populasi dan Sampel Penelitian}

Populasi dalam penelitian ini adalah seluruh konsumen Dunkin Donuts Sukasari, Bogor. Sedangkan dalam penelitian ini teknik penarikan sampel yang digunakan adalah non-probability sampling, di mana teknik pengambilan sampel yang tidak memberikan kesempatan yang sama bagi setiap unsur atau anggota. Penentuan sampel ditentukan secara purposive sampling, karena tidak semua sampel memiliki kriteria yang sesuai dengan fenomena yang diteliti. Adapun kriteria yang dijadikan sebagai sampel penelitian yaitu: konsumen Dunkin Donuts Sukasari, Bogor yang memiliki akun LINE dan yang mengikuti Akun Resmi Dunkin Donuts pada media aplikasi messenger LINE. Besarnya sampel yang diambil dari populasi, digunakan rumus Slovin (Slovin Formula) dengan tingkat kepercayaan $90 \%$ dengan nilai $\mathrm{e}=10 \%$, sehingga didapat angka 99,77 (100) orang.

\section{Jenis dan Sumber Data}

Jenis data yang digunakan adalah Data Kualitatif yang merupakan bukan angka atau tidak dapat dihitung. Data yang digunakan berasal dari buku, artikel jurnal, dan internet, serta berasal dari hasil wawancara dengan pimpinan perusahaan dan karyawan dalam perusahaan. Kemudian ditambah informasiinformasi yang diperoleh dari pihak lain yang berkaitan dengan masalah yang diteliti serta dari beberapa referensi yang dapat mendukung penyelesaian tulisan ini. Disamping itu juga digunakan jenis Data Kuantitatif yang diperoleh dalam bentuk angka yang dapat dihitung, diperoleh dari perhitungan kuisioner yang berhubungan dengan masalah yang dibahas dalam penelitian ini. Sumber data yang digunakan dalam penelitian ini berupa Data Primer yang diperoleh dari menyebarkan secara langsung kuisioner kepada responden terpilih dan Data Sekunder yaitu berupa informasi yang diperoleh dari perusahaan, internet, majalah, koran, dan buku-buku yang berhubungan dengan penelitian.Teknik Pengumpulan Data dalam penelitian ini, melalui Kuesioner terstruktur dan tertutup yang diajukan dalam bentuk tertulis. Peneliti menggunakan Skala Likert (1-5) . Penelitian kepustakaan dengan cara mengumpulkan data melalui beberapa literatur, artikel, karya ilmiah, dan bahan analisis yang berkaitan dengan penelitian ini, dan Obervasi dengan mendatangi tempat penelitian, melakukan wawancara serta mencari informasi yang berkaitan dengan penelitian secara langsung maupun tidak langsung. Dalam penelitian ini ada dua variabel yang digunakan yaitu Promosi Digital LINE sebagai variabel (X) atau independent dan Keputusan pembelian pelanggan yang diberi simbol (Y) sebagai variabel dependent.

\section{Teknik Analisis Data}

Teknik analisis data statistik yang digunakan adalah regresi linier sederhana. Untuk mempermudah perhitungan, peneliti menggunakan alat bantu SPSS V20.0. Uji statistik yang dilakukan dalam penelitian ini, meliputi: Uji Instrumen Penelitian yaitu menggunakan uji validitas dan uji reliabilitas , Uji Asumsi Klasik untuk menguji kelayakan model regresi menggunakan uji normalitas, uji Heteroskedastisitas yang menguji bagaimana jenis dari data yang didapatkan, bersifat homogen atau heterogen, dan uji linieritas dilakukan untuk mengetahui model yang digunakan apakah menggunakan model linier atau tidak. Uji Hipotesis dalam penelitian ini terdiri dari uji regresi sederhana, Uji T, uji koefisien korelasi $(\mathrm{R})$ \& koefisien determinasi $\left(\mathrm{R}^{2}\right)$.

\section{HASIL DAN PEMBAHASAN}

\section{Gambaran Umum Responden}

Berdasarkan hasil data yang telah dikumpulkan dengan melakukan penyebaran kuesioner kepada sampel 100 responden yang merupakan pembeli yang pernah berkunjung dan membeli produk Dunkin Donuts di gerai cabang Sukasari Bogor, maka diketahui gambaran umum mengenai responden melalui kuesioner terhadap pengunjung yang mengikuti akun resmi Dunkin Donuts di media LINE dengan rincian jenis kelamin, usia, pendidikan terakhir, dan pekerjaan adalah sebagai berikut 
Tabel 2. Karakteristik Responden

\begin{tabular}{ccc}
\hline Jenis Kelamin & Responden & $\mathbf{( \% )}$ \\
\hline Laki-laki & 60 & 60 \\
\hline Perempuan & 40 & 40 \\
\hline & & \\
\hline Usia & & 15 \\
\hline Di Bawah 20 Tahun & 15 & 61 \\
\hline 21 -30 Tahun & 61 & 20 \\
\hline 31 - 40 Tahun & 20 & 2 \\
\hline $41-50$ Tahun & 2 & 2 \\
\hline Di Atas 50 Tahun & 2 & 36 \\
\hline \multicolumn{3}{c}{} \\
\hline Pendidikan & Responden \\
\hline SMA/Sederajat & 36 & \\
\hline D3 & 15 & \\
\hline S1 & 37 & \\
\hline S2 & 11 & \\
\hline Lain-lain & 1 & \\
\hline \multicolumn{2}{c}{} \\
\hline Pekerjaan & Responden & Persentase (\%) \\
\hline Pelajar/Mahasiswa & 42 & 42 \\
\hline Karyawan & 28 & 28 \\
\hline Bisnis & 9 & 9 \\
\hline Profesional & 13 & \\
\hline Lain-lain & 8 & \\
\hline
\end{tabular}

\section{Uji Instrument}

Hasil uji validitas, menunjukan nilai Corrected Item-Total Correlation memiliki nilai koefisien positif dan lebih besar dari pada 0,3, sehingga seluruh butir pernyataan yang digunakan pada kuesioner penelitian ini adalah valid. Hasil nilai Cronbach's Alpha seluruh variabel penelitian adalah lebih besar dari 0,6 sehingga layak atau reliabel digunakan untuk menjadi alat ukur instrumen kuesioner dalam penelitian ini.

\section{Uji Asumsi Klasik}

Hasil data Tabel 3., menunjukan sig. 2 tailed bernilai 0,528 . Selain itu grafik normal $p-$ plot menunjukan data menyebar di sekitar garis diagonal dan mengikuti arah garis diagonal maka dapat disimpulkan bahwa model regresi linear sederhana memenuhi asumsi normalitas.
Tabel 3. Uji Normalitas
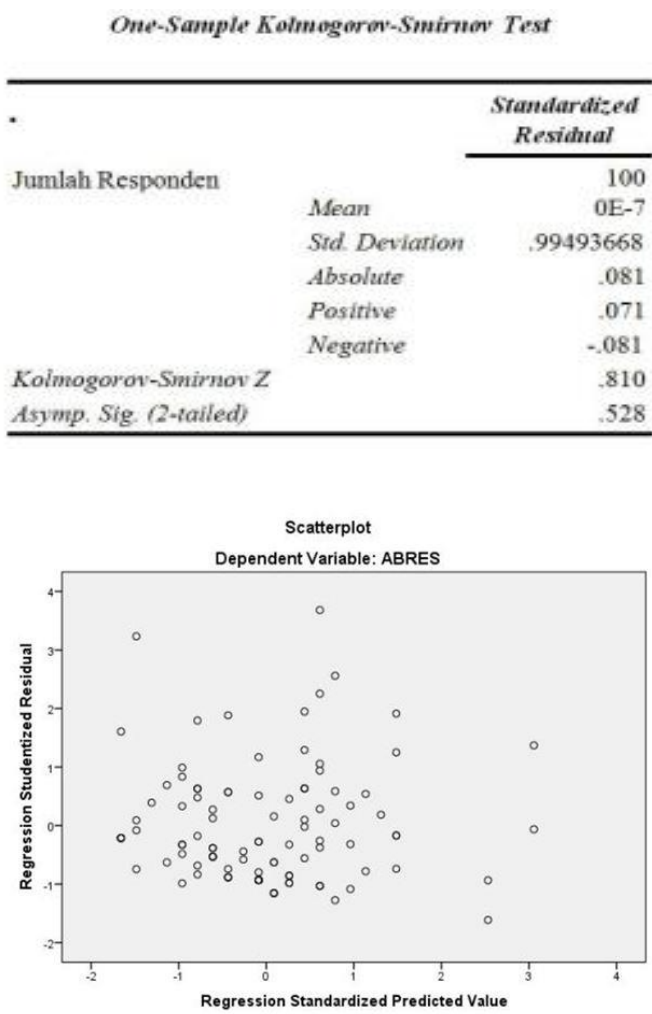

Gambar 5. Uji Heteroskedastisitas

Berdasarkan gambar 5., maka dapat dilihat bahwa titik - titik data menyebar di atas dan di bawah atau di sekitar angka 0 , titik - titik data tidak membentuk pola bergelombang melebar kemudian menyempit dan melebar kembali. Sehingga dapat disimpulkan bahwa data tidak terjadi heteroskedastisitas.

Tabel 4. Uji Linearitas

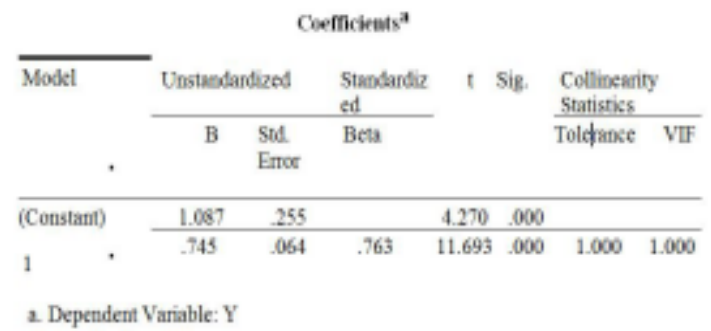




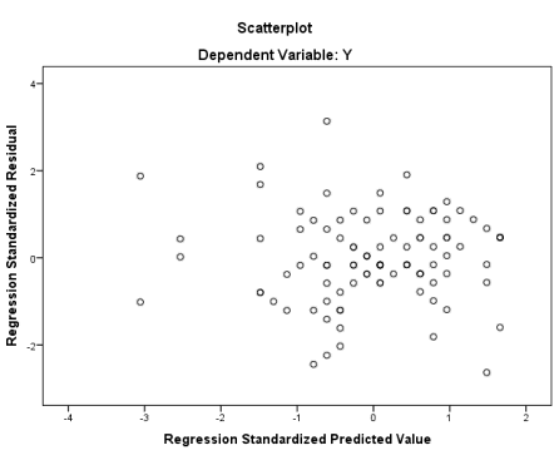

Hasil uji linearitas menunjukan sig. bernilai 0,000. Selain itu grafik scatterplot menunjukan data menyebar di sekitar garis diagonal dan tidak membentuk pola tertentu (acak). Sehingga dapat disimpulkan bahwa data mengalami hubungan yang linier.

Tabel 5. Uji Regresi Sederhana dan Uji T

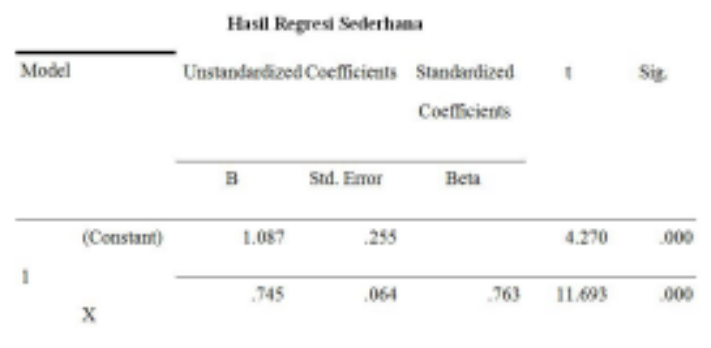

Berdasarkan hasil olahan regresi dengan menggunakan program komputerisasi SPSS versi 20.0, maka dapat disajikan persamaan regresi yaitu sebagai berikut:

\section{$Y=1,087+0,745 X$}

Dari persamaan regresi tersebut, maka dapat diberikan penjelasan sebagai berikut: Nilai koefisien intercept (a) adalah $=1,087$. Nilai konstanta (a) adalah 1,087. Artinya, jika promosi nilainya 1 , maka keputusan pembelian nilainya positif yaitu 1,832 . Nilai Koefisien regresi Promosi Digital LINE sebesar 0,745 dan bertanda positif, berarti bahwa setiap perubahan satu satuan pada Promosi Digital LINE maka nilai Keputusan akan mengalami kenaikan sebesar 0,745 dengan arah yang sama. Hasil persamaan regresi sederhana tersebut menunjukkan pengaruh variabel bebas (Promosi Digital LINE) terhadap variabel terikat (Keputusan Pembelian) pada Dunkin Donuts Sukasari Bogor. Koefisien regresi variabel bebas mempunyai pengaruh yang searah terhadap variabel terikat.

Tabel 6. Uji $\mathrm{T}$

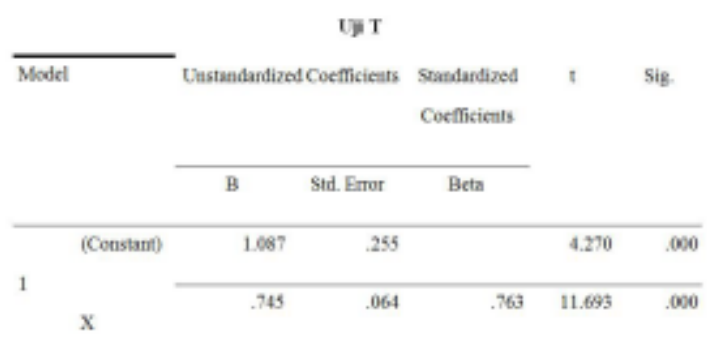

Kriteria signifikasi regresi jika sig < 0,05 maka $\mathrm{H} 1$ diterima atau jika $\mathrm{t}$ hitung $>\mathrm{t}$ tabel maka $\mathrm{H} 1$ diterima (Berpengaruh Signifikan). $\mathrm{t}$ tabel $=$ tabel distribusi $\mathrm{t}$ untuk taraf nyata 5\% dengan derajat kepercayaan (df $=\mathrm{n}-2)=(100-2=98) \mathrm{t}$ tabel $=1,984467$.

Dari hasil pengujian yang dilakukan (uji t) pada tabel 6., variabel promosi digital LINE mempunyai nilai $\mathrm{t}$ hitung $>\mathrm{t}$ tabel $(11,693>1,984467)$ dan berdasarkan signifikansi, nilainya kurang dari 0,05 $(0,000<$ 0,05), maka H1 diterima. Dengan demikian, dapat disimpulkan bahwa Promosi Digital LINE berpengaruh positif secara signifikan terhadap Keputusan Pembelian di Dunkin Donuts Sukasari, Bogor.

Tabel 7. Uji R dan R2

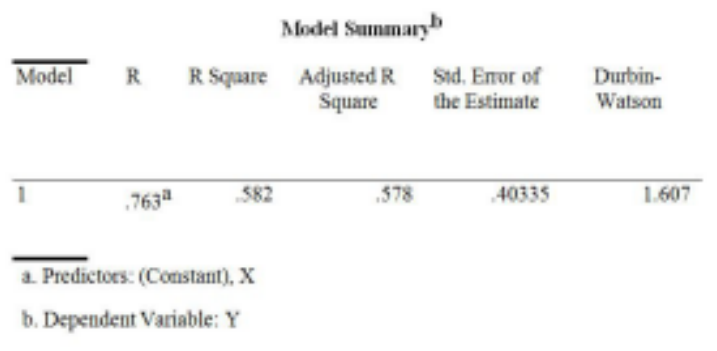

Pada tabel 7., nilai $\mathrm{R}$ (Koefisien Korelasi) yaitu sebesar 0.763, hal ini menunjukan bahwa adanya hubungan yang positif antara variabel independen promosi digital LINE dan variabel dependen keputusan pembelian, serta dikatakan kuat karena 
mendekati nilai 1. Sedangkan untuk mengetahui besarnya hubungan variabel bebas berpengaruh terhadap variabel terikat dapat dilihat dari besarnya nilai koefisien $\mathrm{R}$ square (Koefisien Determinasi) yang diperoleh sebesar 0,582 . Hal ini berarti bahwa variabel bebas Promosi Digital LINE mempunyai kontribusi sebesar 58,2\% terhadap variabel terikat Keputusan Pembelian (Y). Sedangkan sisanya yaitu sebesar $41,8 \%$ dipengaruhi oleh variabel lainya yang tidak diteliti dalam penelitian ini.

\section{SIMPULAN}

Dari hasil pengujian penelitian yang telah dilakukan, didapat beberapa hasil temuan diantaranya: berdasarkan hasil uji t., variabel promosi digital LINE mempunyai nilai t hitung $>\mathrm{t}$ tabel $(11,693>1,984467)$ dan berdasarkan signifikansi, nilainya kurang dari $0,05(0,000<0,05)$, maka Hipotesis $(\mathrm{H} 1)$ diterima, berdasarkan koefisien korelasi diperoleh nilai $(\mathrm{R})$ sebesar 0.763 , sehingga terdapat hubungan yang positip dan kuat antara variabel promosi digital LINE dengan variabel keputusan pembelian. Berdasarkan koefisien determinasi $\left(\mathrm{R}^{2}\right)$ terdapat kontribusi pengaruh promosi digital LINE sebesar 58,2\% terhadap keputusan pembelian. Sehingga dapat disimpulkan bahwa promosi digital LINE berpengaruh positif dan signifikan terhadap keputusan pembelian di Dunkin Donuts Sukasari, Bogor dengan kontribusi pengaruhnya sebesar $58,2 \%$.

\section{DAFTAR PUSTAKA}

Agus, Hermawan. 2012. Komunikasi Pemasaran. Jakarta: Erlangga

Kaplan, M. A and Haenlein. M. 2010. Users of the world, unite! The challenges and opportunities of Social Media. Business Horizons 53(1) Jan-Feb 2010 59-68

Kotler, Philip R., Bowen, John T \& Makens, James. 2012. Marketing for Hospitality and Tourism: Sixth Edition. Pearson Education Limited. London.
Kotler, Philip. and Keller, Kevin Lane. 2012. Marketing Management $14 e$. England: Pearson Education

Kotler, Philip. \& Gary Armstrong. 2014. Principle Of Marketing, 15th edition. New Jersey: Pearson Prentice Hall.

Kotler, Philip. 2009. Manajemen Pemasaran. Jakarta: Erlangga

Morrison. 2010. Periklanan Komunikasi Pemasaran Terpadu. Jakarta: Kencana Prenada Media Group

Sanjaya, Ridwan dan Josua Tarigan. 2009. Creative Digital Marketing. PT Elex Media Komputindo. Jakarta

Sibero, Alexander F. K. 2011, Kitab Suci Web Programing: MediaKom. Yogyakarta.

Solomon, Michael. R. 2015. Consumer Behavior: Buying, Having and Being, 11thEdition. New Jersey: Prentice-Hall.

Sugiarto. Tonny dan Djiko, Sudibyo. 2015. Metode Penelitian Hospitality Pariwisata.Tangerang. PT Matana Publishing Utama.

Sugiyono. 2014. Metode Penelitian Kuantitatif Kualitatif dan R\&D.Bandung: Alfabeta.

Sumarwan, Ujang. 2014. Perilaku Konsumen: Teori dan Penerapannya dalam Pemasaran. Bogor: Ghalia Indonesia

Andi. Tjiptono, Fandy dan Gregorius Chandra. 2012. Pemasaran Strategik. Yogyakarta, ANDI

Tuten, Tracy L. 2008. Advertising 2.0 Social Media Marketing in a Web 2.0 World. Connecticut: Praeger

Weinberg, Tamar. 2009. The New Community Rules: Marketing on the Social Web.California: O' Reilly

Dewi, Ni Made Arianita, dan Elsie Oktivera. 2018. Analisis Iklan Instant Messaging Line Mempengaruhi 
Minat Beli Konsumen Starbucks Di Jakarta Selatan. Sekolah Tinggi Tarakanita. Jakarta.

Meyliana. 2011. Analisis Strategi EMarketing dan Implementasi Pada Rental Company.Jakarta

Mileva, Lubiana. dan Fauzi, Achmad. 2018. Pengaruh Social Media Marketing Terhadap Keputusan Pembelian (Survei Online pada Mahasiswa Sarjana Jurusan Ilmu Administrasi Bisnis Angkatan 2014/2015 Fakultas Ilmu Administrasi Universitas Brawijaya yang Membeli Starbucks Menggunakan LINE). Ilmu Administrasi. Universitas Brawijaya. Malang.

Neti, Sisira. 2011. Social Media and it's Role in Marketing. International
Journal of Enterprise Computing and Business Systems, Vol. I Issue 2.

Rismayanti, Puji. 2017. Strategi Komunikasi Pemasaran Dalam Meningkatkan Penjualan.Fakultas Ilmu Sosial dan Humaniora. Universitas Islam Negeri Sunan Kalijaga. Yogyakarta.

Setia, Tatang. 2015. Pengaruh Periklanan, Promosi Penjualan, dan Hubungan Masyarakat Terhadap Keputuasn Wisatawan Berwisata di Lembah Hijau Bandar Lampung (Suatu Survei pada Mahasiswa FEB Universitas Lampung). Fakultas Ekonomi dan Bisnis. Universitas Bandar Lampung. Lampung.

Kurniawan, Arif. 2019. "Data Penjualan Donat di Dunkin Donuts Sukasari Bogor".Hasil Wawancara, 18 Januari 2020 . 